Rubén Peretó RIVAS*

\title{
DREAMS IN EVAGRIUS PONTICUS' LIFE AND TEACHING
}

There are not many lives whose destiny is decided through a revelation obtained from a dream or a vision. In any case, the decision would be judged as rash, irresponsible and irrational. However, that was the case of Evagrius of Pontus, an Egyptian desert monk to whom is due the first systematization of Christian mystics.

Born in the region of Pontus in 345, he was the son of a chorbishop of Ibora and was educated in Neocaesarea by Basil the Great, who ordained him as reader. Leaving his homeland in 379, Evagrius spent about three years in Constantinople, where he was made archdeacon by his spiritual father, Gregory of Nazianzus, and participated in ecclesiastical matters, including the Second Ecumenical Council (381). It was in this city, after Gregory's departure, that he was involved in a complex sentimental situation with the wife of a court official, and received a vision in which he was ordered to leave the city and his work immediately. And so he did. He unexpectedly moved to Jerusalem, where he joined the monastic communities of Melania the Elder and Rufinus, taking monastic vows in 383 . He migrated to Egypt, where he met and studied under many of the central figures of Egyptian monasticism, soon becoming one himself.

The turning point in the life of Evagrius is brought about by a phenomenon that his biographer calls a vision and that, as in a dream, consists in the representation of auditory, visual sensitive images outside reality that leave some kind of message provoking changes in the subject's behavior. It is no wonder that after this experience Evagrius should attribute such consequence to dreams throughout the different stages of the spiritual journey the monk must undergo. In this work I propose to investigate some aspects related to dreams and visions, pointing out the intervening psychological elements and their specular function.

1. Vision as a Turning Point in Evagrius' Life. In The Lausiac History, when narrating the life of Evagrius of Pontus, Palladius relates the following:

${ }^{*}$ Prof. dr Rubén Peretó Rivas - Professor Ordinary in the Department of Philosophy (Chair of History of Medieval Philosophy) at the Faculty of Philosophy and Letters of National University of Cuyo (CONICET) in Mendoza (Argentina); e-mail: rpereto@gmail.com. 
"After he had been at prayer a short time, there appeared to him an angelic vision [...] The angel said: «Listen to a friend. It will not be safe for you to stay on this town». Evagrius told him: «Let God free me from this predicament, and if you still see me in Constantinople, know that I would undergo this punishment without complaint». Then the vision spoke: «I will bring the Gospel; you swear on it that you will leave this town and will have concern for your soul, and I will free you from this strait». The Gospel was brought then and he swore to him by it: «Except for this one day when I am packing to leave, I shall not tarry here longer». As the oath was finished he came back out of his ecstasy. He got up and decided that «even if this oath was made in my vision, nevertheless I did swear it». Putting everything aboard ship, he went on to Jerusalem"1.

The text shows several relevant elements: Evagrius has a vision while enduring a particularly stressful situation. In it he is ordered by an angel to leave Constantinople and made to swear on the Gospels that he will flee from the city and change his life to devote himself to the salvation of his soul. In exchange the angel will free Evagrius from the embarrassing situation that he was in. Although the oath is made in a vision and not in a state of full consciousness, when he awakes he decides to keep it and next day he embarks for Jerusalem and a changed life: from being archdeacon of Nectarius, archbishop of Constantinople and with an eminent position at court, he becomes an unknown and sickly inhabitant of a Jerusalem monastery. A few months later, and following Melania's request, he decides to travel to Egypt and become a hermit in the desert of Nitria. A radical change of life has been decided as the effect of a vision. What opinion do authors of early Christianity hold about this type of phenomena, visions and dreams? Which was the difference, if any, between dreams and visions? In which way do they influence and have an actual presence in the life and spiritual experience in early Christian writers?

2. Dreams in Patristic Authors. The cultural and religious space in which Evagrius lives and narrates his dream experiences is a frame of reference that must be carefully considered in order to understand, in the first place, how close the author was to this type of phenomena and, above all, to be able to weigh his contribution, original treatment and evaluation of dreams.

Among the eastern Fathers, Athanasius considered that dreams were a sort of revelation of the invisible world, although he was careful to point out the errors that to which a wrong interpretation might lead ${ }^{2}$. It is in his Vita Antonii, where angels, demons, extra sensible knowledge and healing powers are

${ }^{1}$ Palladius, Historia Lausiaca 38, 4. 6-7, ed. C. Butler: The Lausiac History of Palladius, vol. 2: The Greek Text edited with introduction and notes, Texts and Studies VI/2, Cambridge 1904, 118-119, transl. R.T. Meyer: Palladius, The Lausiac History, Ancient Christian Writers 34, London 1965, 111-112.

${ }^{2}$ Cf. Athanasius Alexandrinus, Epistula festalis 13, 7, PG 26, 1418. 
described in greater detail. Beyond the scientific criteria that may be adopted when reading this work, there is no doubt that the view offered by psychology allows one to visualize an objective reality that the author is well aware of. On the other hand, it is evident that for Athanasius the human soul may possess a direct communication with the spiritual world, beyond the means of reason or sensitive experience.

The Cappadocians also insist on the importance that must be attributed to dreams. Gregory of Nyssa in De opificio hominis, deals with the theme in a concrete way. When a person dreams, he explains, his senses and intelligence rest while his less rational parts take over. But reason is not asleep; it lies shining like embers that may light up at any moment ${ }^{3}$. In some cases dreams can be even interpreted so that through them the will of God is known. That was the case of Daniel and Joseph ${ }^{4}$. According to the Nyssen, there exists a kind of pre-vision that reaches a person through unknown means by the irrational side of the soul and, through it, God communicates directly to him or her. Dreams, however, are not only peopled by possible preternatural communications, they may simply be the result of mere memories of occupations or daily happenings. They may also reflect bodily conditions, hunger or thirst, or the person's emotional state. They may even offer clues leading to the causes of diseases of the body. Further on, Gregory affirms that dreams form a person's character and that, therefore, the fantasies of the courageous will be different from those of the coward, just as those of the lascivious will differ from those of the chaste. What happens is that, while in a wakeful state fantasies are produced by the intellect, during sleep they are produced by the irrational parts of the soul, even including fantasies similar to those things that each person does habitually when awake.

In his commentary of Commentary on Isaiah, Basil the Great explains that the enigmas of dreams are strictly related to what the Scriptures mean in an allegorical or hidden way. Thus, through the gift of prophesy, Joseph and Daniel were able to interpret dreams, since the force of reason is not strong enough by itself to reach the truth ${ }^{5}$. However, Basil's epistles contain a very cautious criterion about dreams. He acknowledges that the development of human psyche at a certain level may not be controlled, which is why he warns Gregory of Nazianzus, that it is better not to sleep too much so that the mind may not be open to unbridled fantasies ${ }^{6}$.

It is Gregory himself who speaks of dreams not from a theological perspective but from that of personal experience. In the second book of his Carmina

${ }^{3}$ Cf. Gregorius Nyssenus, De opificio hominis 13, 168, ed. J. Laplace, SCh 6, Paris 1944, 139.

${ }^{4}$ Cf. ibidem 13, 172b, SCh 6, 142.

${ }^{5}$ Cf. Basilius Caesariensis, Enarratio in Isaiam prophetam 6-7, PG 30, 128-129, transl. N.A. Lipatov: St. Basil the Great, Commentary on the Prophet Isaiah, Cambridge 2001, 1-3.

${ }^{6}$ Cf. idem, Epistula 2, 6, PG 32, 232-233, transl. R. Deferrari, vol. 1: Letters 1-58, Cambridge MA 1926, 24-25. 
he says that God had taught him from childhood through night-time dreams and in this way he reached the heights of contemplation ${ }^{7}$. Thus it was that he chose a life of chastity and continence, avoiding matrimony ${ }^{8}$. But he cautions that the devil may use dreams in a way to deceive men, so that one should be very careful about their contents?

John Chrysostom explains in his Commentary on the Acts of the Apostles that grace is imparted to certain persons through dreams while to others it is bestowed openly, and it is because of this that the prophets saw and received their revelations through dreams ${ }^{10}$. These are sent to those men whose will conforms to the divine, since they do not need visions or any other type of supernatural manifestation; such was the case of Joseph, Jesus' adopted father, and that of Paul and Peter ${ }^{11}$. Chrysostom is careful to explain that we are not responsible for our dreams, so that we are not guilty of whatever occurs in them. Although no physical reality is revealed, they do reveal a spiritual reality in which men may even be struck by angels. Dreams also show the state of the human soul, its bad conscience and bad temper, and they can even dissuade people from immoral desires ${ }^{12}$.

Perhaps the most relevant treaty of the epoch on this matter is the work of Synesius of Cyrene, On Dreams ${ }^{13}$. The author considers that the representative faculty serves as a basis to explain the genesis of dreams. He draws a distinction between prophetic dreams and oneiric visions, and insists on the importance of the subconscious in literary creation. Finally, he considers that each dream must be interpreted by itself and that universal sympátheia serves as a rational basis for divination.

The Latin Fathers have also expressed themselves about dreams, Ambrose most conclusively of them all. In his Letter to Theodosius he affirms that God had forbidden him to celebrate Holy Communion with the Emperor unless the latter repented. He is very careful to relate the details of the warning dream, and clarifies that it occurred in the middle of the night, when he was anxious about

\footnotetext{
${ }^{7}$ Cf. Gregorius Nazianzenus, Carmina II 1, 994-995, v. 98, PG 37, 1450.

${ }^{8}$ Cf. ibidem II 1, 930-933, v. 217-292, PG 37, 1367-1374.

${ }^{9}$ Cf. ibidem I 2, 33, 608-609, v. 205-224, PG 37, 943-944.

${ }^{10}$ Cf. Joannes Chrysostomus, In Acta Apostolorum hom. 5, 1, PG 60, 50-51, trans1. M. Merino Rodríguez: Juan Crisóstomo, Homilías a los Hechos de los Apóstoles, Biblioteca de Patrística 80, Madrid 2010, 219.

${ }^{11}$ Cf. idem, In Matthaeum hom. 4, 10-11, 18; 5, 5, ed. and transl. D. Ruíz Bueno: Obras de San Juan Crisostomo, vol. 2: Homilias sobre el Evangelio de San Mateo, Biblioteca de Autores Cristianos, ed. bilingüe griego/español, Madrid 2007, 356.

${ }^{12}$ Cf. idem, In epistulam ad Romanos hom. 24, PG 60, 621-628, transl. B. Bejarano: San Juan Crisóstomo, Homilías sobre la Carta a los Romanos, t. 1, Apostolado Mariano, Los Santos Padres 21, Seville 1990, 54; idem, In Matthaeum hom. 53, 6, ed. Ruíz Bueno, p. 378.

${ }^{13}$ Cf. Synesius Cyrenensis, De insomniis 1-3, PG 66, 1281-1288, transl. F.A. García Romero: Sobre los sueños, in: Sinesio de Cirene, Himnos y tratados, introducción, traducción y notas F.A. García Romero, Madrid 1993, 250-259.
} 
what he should do the next day ${ }^{14}$. In the book dedicated to his brother Satyr's death, he compares the painful nights provoked by the separation from his brother to the joys that he experiences at that moment due to the dreams that bring back Satyr's presence to reality ${ }^{15}$. But apart from these personal matters, the Bishop of Milan declares that the Holy Spirit speaks through dreams, many times served by an angel, since these beings are led by the Spirit. It was the Spirit who not only confirmed his presence to Joseph in dreams but also addressed himself to Paul through visions and intuitions, and spoke clearly to Peter in the dream that took place in Joppa. About this deed in particular he continues at length and ends by saying: "How clearly did the Holy Spirit express his own power!"16

Some decades ago Augustine's dreams were the object of an excellent monograph to which I refer the reader ${ }^{17}$. It is sufficient to say here that the reflections on dreaming by the bishop of Hippo include elements from different origins. Although angels and demons are objects of influence, imagination and its creating power also form part of them. For Augustine, however, it is not only a question proper to human psychology, since he considers that dreams play a role in the knowledge of God. The last books of De Trinitate show us that the author is concerned with searching for the image of God in the human spirit and, on understanding its functioning, to penetrate even more deeply into that inner space in which humanity finds itself with God. That is why all the theories that Augustine proposes about dreams are in harmony with his insistence on the potency of God's grace: without the express aid of some divine messenger the human soul is unable to possess a dream that might contribute any real knowledge. Even so, dreams using corporeal images are still a "vision in enigma", without any relation to the face-to-face vision of glory ${ }^{18}$.

Jerome details carefully the awful dream in which he saw himself as the protagonist of his own judgment. "You are a liar", he hears, "because you are a follower of Cicero and not of Christ"19. Beyond his personal experience, in his commentary on the passage Jer 23:25-32, his opinion is that dreams are a kind of prophesy that God may use as a vehicle of revelation for the soul. He introduces a distinction: they may be a valuable revelation provided that the person is close to God, but they may be idolatrous when they are dreamed and interpreted according to personal interest and without being related to the divine law. The value of dreams, in fact, depends on the person who receives them and on the person who interprets them ${ }^{20}$.

\footnotetext{
${ }^{14} \mathrm{Cf}$. Ambrosius Mediolanensis, Epistula [ad Theodosium imperatorem] 51, 14, PL 16, 1213.

${ }^{15}$ Cf. idem, De excessu fratris Satyri I 72-73, PL 16, 1369-1370.

${ }^{16}$ Idem, De Spiritu Sancto II 5, 37, PL 16, 781; II 10, 102-104, PL 16, 796-797.

${ }^{17}$ Cf. M. Dulaey, Le rêves dans la vie et la penseé de saint Augustin, Paris 1973.

${ }^{18}$ Cf. Augustinus Hipponensis, De genesi ad litteram 12, 28, ed. J. Zycha. CSEL 28/1, Vindo-

${ }^{19}$ Hieronymus, Epistula 22 [ad Eustochium], 30, PL 22, 416, my own translation.

${ }^{20} \mathrm{Cf}$. idem, Commentaria in Ieremiam 4, 23, PL 24, 858-861.
} bonae $1894,422$. 
The last of the Latin Fathers was Gregory the Great who also discusses the importance and meaning of dreams in two of his works with practically identical words. He considers that dreams have six different sources: a full or empty stomach, illusions, our thoughts combined with illusions, revelations or our thoughts combined with revelations. After giving examples of each type of dream, he assures that one must be very careful not to place one's faith in them since it is very difficult to discern their origin. The saints are able to distinguish true revelations from voices, and images from illusions or mirages through an inner sensitivity, and always to recognize when they receive a communication from a good spirit or when they are facing illusions; this is not the case with all mortals ${ }^{21}$.

3. Dreams and Visions in Evagrius of Pontus. Although written over more than five decades ago, François Refoulé's article, Rêves et vie spirituelle d'après Évagre le Pontique, remains essential when talking about the dreams of Evagrius of Pontus ${ }^{22}$. This is an extensive and exhaustive work in which the author analyzes dreams in the Evagrian oeuvre by criteria that establish close connections between spirituality and psychology. Indeed, it is a work that needs to be updated since at the time of writing the critical editions of the Evagrian corpus were not available, so the text of Patrologia Graeca was commonly used. Since then an abundant secondary bibliography about the author is available and much of it indispensable for the study of Evagrian thought ${ }^{23}$.

However, what Refoulé considers Evagrius' "original contributions" about dreams, are just a starting point for this research. Among these contributions, in the first place, is his insistence on psychological factors in the formation of dreams. For Evagrius, passions or tendencies are what make up their origin, be they conscious or unconscious. But this emotional life is differentiated by a hierarchy according to the three levels of the soul, such as the Platonic school teaches. He also proposes a classification of dreams in eight types based on eight logismoi or evil thoughts.

In the second place, the connection between dreams and the life of passions and emotions is a privileged means for exploring the irrational parts of the soul. Finally, Evagrius' third contribution is that dreams possess a significant influence over the spirit and over life in a state of vigil, due to the persistent influx of passions over the spirit ${ }^{24}$.

${ }^{21}$ Cf. Gregorius Magnus, Dialogi 4, 50, ed. A. de Vogüé - P. Antin, SCh 265, Paris 1980, 175; idem, Moralia in Iob 8, 42-43, ed. R. Guillet - A. de Gaudemaris, SCh 32bis, Paris 1975, 267.

${ }^{22}$ Cf. F. Refoulé, Rêves et vie spirituelle d'après Évagre le Pontique, VS Supplément 56 (1961) 470-516.

${ }^{23}$ Recent works cf. include: J. Konstantinovsky, Evagrius of Pontus: The Making of a Gnostic, Farnham 2013; A. Casiday, Evagrius Ponticus, London 2006; R.E. Sinkewicz, Evagrius of Pontus. The Greek Ascetic Corpus, Oxford Early Christian Studies, Oxford 2003.

${ }^{24} \mathrm{Cf}$. Refoulé, Rêves et vie spirituelle d'après Évagre le Pontique, p. 512. 
The studies of contemporary psychology about dreams - to wit those by Freud and Jung - start from the statement that they are individual phenomena which, in order to be understood, require a psychological approach that implies exclusion from the religious field. This situation was the reason that scholars were for many years reluctant to use ancient texts for the study of dreams, a situation that has been reverted in the last decades, as demonstrated by the vast bibliographies on the subject ${ }^{25}$. Bart Koet points out that patristic writers took an interest in dreams as a way of knowing about the future, or rather as a rhetorical resource destined to introduce their ideas in a convincing way to their audiences. However, they did not see in them a way of knowing or reflecting, as in a mirror, the past and with it the person's inner being ${ }^{26}$. This is, in fact, the situation observed in the majority of the cases. Evagrius, however, is a clear exception. It may perhaps be excessive to declare that, as does Refoulé, Evagrius had a "psychological" interest in dreams, taking this term as it is taken in the contemporary world. But there is no doubt that the Evagrius does not show the slightest interest in dreams as predictive phenomena for future events; for him, dreams are a privileged way of getting to know the person's inner being. In this sense, the "psychological" interest of the author in oneiric activity can be affirmed. The most significant example of this is his treaty Antirrhetikos, in which he describes in fine detail how images and stories are interwoven in dreams to show the intricacies of the monk's psychology when assailed by the eight logismoi or evil thoughts ${ }^{27}$. From this point of view, Evagrius Pontus makes an extremely original contribution to the subject of dreams.

At this point, some explanation should be given concerning the distinction between dreams and visions. This matter is a problem that runs through the writings of all the authors of late antiquity, since it is not clear whether they establish a real distinction between both phenomena, considering them as belonging to different species, or even assimilating them. Neither is it clear in Evagrius' works whether he is making a reference to dreams or to daytime visions. Faced

${ }^{25} \mathrm{Cf}$. J. Amat, Songes et visions. L'au-delà dans la littérature latine tardive, Paris 1985; S. Kruger, Dreaming in the Middle Ages, Cambridge 1996; J. Husser, Dreams and Dream Narratives in the Biblical World, Sheffield 1999; R. Gnuse, Dream and Dream Reports in the Writings of Josephus, Leiden 1997; J. Gollnick, The Religious Dreamworld of Apuleius' "Metamorphoses". Recovering a Forgotten Hermeneutic, Ontario 1999; F. Flannery-Dailey, Dreamers, Scribes and Priests. Jewish Dreams in the Hellenistic and Roman Eras, Leiden 2004; J.G. Barr, Willing to Know God: Dreamers and Visionaries in Later Middle Ages, Columbus 2010; J. Bilbija, The Dream in Antiquity: Aspects and Analyses, Amsterdam 2012.

${ }^{26}$ Cf. B. Koet, Introducing Dreaming from Hermas to Aquinas, in: Dreams as Divine Communication in Christianity: From Hermas to Aquinas, ed. idem, Leuven 2012, 3.

${ }^{27}$ Cf. W. Frankenberg, Euagrius Ponticus, Abhandlungen der königlichen Gesellschaft der Wissenschaften zu Göttingen, Philologisch-historische Klasse, Neue Folge 13/2, Berlin 1912, 472-544, English translation - D. Brakke: Evagrius of Pontus. Talking Back. A Monastic Handbook for Combating Demons, Collegeville Minn. 1989. 
with this situation there are two possible alternative answers. The first consists in considering, from a methodological point of view, dreams as equivalent to visions. This position finds a champion within patristic literature. We are referring to Jerome who establishes a total equivalence between Joseph's dream, in which the angel tells him not to fear to receive Mary as his wife (Mt 1:20); his dream of the Wise Men in which an angel also warns them not to return to see Herod (Mt 2:12), with the apparition of the angels to the shepherds (Lk 2:10); and the "revelation" that Simon and Anne receive when they see the Infant Jesus presented by his parents in the Temple and recognize him as the promised Messiah (Lk 2:17-38) ${ }^{28}$. However, it would not seem altogether adequate to maintain such a wide equivalence without trying to find some kind of classification that might allow for more precise distinctions. Grey reports a possible division starting from the types of dreams found in Flavius Josephus' work: 1) Dreams with auditory messages, which are the most common in the Bible; 2) dreams with visual symbols, like those appearing in the Book of Daniel; and $3)$ dreams with visual images or $\varepsilon i \delta \omega \lambda$ ov generally found in Greek texts ${ }^{29}$. But this classification does not allow us to distinguish dreams from visions.

Macrobius, in his Commentary on Scipio's Dream, also classifies dreams. He writes:

"All dreams may be classified under five main types: there is the enigmatic dream, in Greek oneiros, in Latin somnium; second, there is the prophetic vision, in Greek horama, in Latin visio; third, there is the oracular dream, in Greek chrematismos, in Latin oraculum; fourth, there is the nightmare, in Greek enypnion, in Latin insomnium; and last, the apparition, in Greek phantasma, which Cicero, when he has occasion to use the word, calls visum" ${ }^{\prime 30}$.

This last type, the phantasma or visum, is described in the following way:

"The apparition (phantasma or visum) comes upon one in the moment between wakefulness and slumber, in the so-called «first cloud of sleep». In this drowsy condition he thinks he is still fully awake and imagines he sees specters rushing at him or wandering vaguely about $[\ldots]^{\prime 31}$.

These visions are produced when the person is in a state of diminished conscience, just as (s)he begins to fall asleep, the moment now known as Stage 1 of sleep, verified during the first ten minutes of a person's falling asleep. Contemporary science affirms that during this stage hallucinations or short dreams can be produced during which vividly colored images can be seen.

${ }^{28} \mathrm{Cf}$. Hieronymus, De virginitate beatae Mariae 8, PL 23, 200.

${ }^{29}$ Cf. R. Gray, Prophetic Figures in Late Second Temple Jewish Palestine: The Evidence from Josephus, Oxford 1993, 107-110, quoted by Gnuse, Dream and Dream Reports, p. 16.

${ }^{30}$ Macrobius, Commentarii in Somnium Scipionis I 3, 1, ed. J.A. Willis, vol. 2, Bibliotheca Scriptorum Graecorum et Romanorum Teubneriana, Leipzig 1970², 8, transl. W.H. Stahl: Commentary on the Dream of Scipio by Macrobius, New York 1990, 87.

${ }^{31}$ Cf. ibidem I 3, 7, ed. Willis, vol. 2, p. 10, transl. Stahl, p. 89. 
Could this be the case of visions Evagrius talks about? Although both descriptions of Macrobius and of science seem to lead us to this interpretation, what is certain is that the moment when they are produced appears perfectly fixed. In his treaty on On Thoughts, he writes:

"This is how the anchorites are tempted by the demons in the daytime and fall victim to various thoughts, but in the night-time during sleep they fight with winged asps, are encircled by carnivorous wild beasts, entwined by serpents, and cast down from high mountains. It sometimes happens that even after awakening they are again encircled by the same wild beasts and see their cell all afire and filled with smoke. And when they do not give in to these fantasies nor fall into cowardice, they in turn see the demons immediately transform into women who conduct themselves with wanton indecency and wish to play shameful games" ${ }^{\prime 32}$.

Evagrius tells what happens when the monk awakens, for which he uses the verb $\delta \imath v \pi v_{i} \zeta \omega$ which does not suggest any specific space of determined time. Visions occur, therefore, when the monk is fully conscious, already awake, and not in the intermediate stages between sleep and vigil. However, these images recognize their origin in dreams. They are particularly vivid, in such a way that they mobilize passions, both irascible and concupiscible, during the day, and they are intense dream residues that in the form of images, deeply impressed in the memory, transform the monk's affections. We are thus far from hallucinations that suppose states near to the pathological. The close relation between these "phantoms" or images and the preceding dreams is evidenced by Evagrius himself in the following few words:

"For the irascible part is very rapidly tempted the next day when it has been troubled the night before, and the concupiscible part readily welcomes thoughts of fornication when it has been previously agitated in the fantasies of its sleep" ${ }^{33}$.

4. Dreams and Their Influence on Wakefulness. Evagrius' argument leads to a relevant conclusion: dreams possess a real influence during the daytime, because they mobilize and motivate human conduct. This is an idea present in many areas of ancient culture. Aristotle, for example, wrote:

"For as when we are about to act [in waking hours], or are engaged in any course of action, or have already performed certain actions, we often find ourselves concerned with these actions, or performing them, in a vivid dream; the cause whereof is that the dream-movement has had a way paved for it from the original movements set up in the daytime; exactly so, but conversely, it

${ }^{32}$ Evagrius Ponticus, De malignis cogitationibus 27, ed. A.C. Guillaumont - P. Géhin, SCh 438, Paris 1998, 250, transl. R.E. Sinkewicz: On Thoughts, in: idem, Evagrius of Pontus, p. 172.

${ }^{33}$ Ibidem. 
must happen that the movements set up first in sleep should also prove to be starting-points of actions to be performed in the daytime, since the recurrence by day of the thought of these actions also has had its way paved for it in the images before the mind at night" ${ }^{\prime 34}$.

The idea remains in the case of Christian authors but with a reference to the influence pertaining to the memory of erotic dreams in mobilizing the passions during the period of vigil ${ }^{35}$. For his part, Evagrius agrees with this line of thought but for him the oneiric influence is not limited to the concupiscible appetite but includes the irascible as well, and this process weakens the soul, thus being an obstacle to reaching his objective of apátheia.

Chapter 28 in his treaty On Thoughts presents an analysis of how demons provoke a monk's dreams, urging him to consent to more subtle evil thoughts, like vainglory or sadness. He begins by explaining that this occurs "When the demons have not been able to trouble the irascible or concupiscible part at night $[\ldots]^{\prime 36}$ that is to say, when the monk has reached a certain state of perfection or control over his passions. These are not images that will storm the monk during the first stretches of the monastic road but rather when he has already journeyed a good way and even when he has reached apátheia, which in no way implies immunity from passions.

The first type of images that appear are those destined to provoke vainglory:

"Frequently one sees oneself rebuking demons, healing certain bodily conditions, or wearing the clothing of a shepherd and pasturing a little flock. And immediately upon waking one gets a fantasy of the priesthood and then spends the entire day thinking through the things that that involves; or as if the charisma of healings were about to be granted, one sees in advance the miracles that happen and fantasizes about the people who will be healed, honours coming from brothers, and the gifts brought by outsiders, all those that come from Egypt and also from abroad, drawn by our renown" ${ }^{37}$.

In this paragraph the mechanism of night-time dreams and their influence during the daytime vigil appear: images are presented in which the monk sees himself exalted through various means and then, "spends the entire day thinking through the things that that involves", or "fantasizes about" the images that have peopled his dreams. The connection with causality is established. It is the dreams occasioned by demons, according to Evagrius, that cause daytime fantasies and allow the development of the logismos of vainglory or $\kappa \varepsilon v o \delta o \xi i \alpha$.

${ }^{34}$ Aristoteles, De divinatione per somnum 1, 463 A, ed. W.D. Ross, in: Aristoteles, Parva Naturalia (with extensive commentary in English), Oxford, 1955, 39, transl. J.I. Beare: On Prophesying by Dreams, New York 1966, 235.

${ }^{35}$ Cf. for example: Joannes Cassianus, Institutiones VI 7; Joannes Climacus, Scala Paradisi 15.

${ }^{36}$ Evagrius Ponticus, De malignis cogitationibus 28, SCh 438, 252, transl. Sinkewicz, p. 173.

${ }^{37}$ Ibidem. 
Evagrius describes a second type of images provoking an even more subtle temptation, that of sadness:

"Often they cast anchorites into an inconsolable sadness by showing them members of their families in sickness or in danger on land or at sea. Sometimes they predict to the brothers themselves in dreams the shipwrecks of the monastic life, throwing down from high ladders those who have climbed up on them and in turn leaving them blind and feeling their way along the walls" ${ }^{\prime 38}$.

They describe two ways in which dreams can provoke sadness: distance from family affections and the sensation of failure of their own lives. Both ways are related to the monastic way of life and question its sense. Evagrius suggests that during sleep, the fantasies imposed by demons lead the monk to ask himself what sense there was in abandoning his parents and choosing a life of sacrifice and penance. Has he wasted his life in an illusion which has revealed itself to be false? This is the possibility that generates an inconsolable sadness ( $\lambda \hat{v} \pi \eta \dot{\alpha} \pi \alpha \rho \eta \gamma o ́ \rho \eta \tau o \varsigma)$ which is a kind of blindness in the monk who begins to go through life guided only by his sense of touch. This metaphor used by Evagrius is easily identifiable with those usually associated, in Christian mystics, to temptations against faith. Indeed, behind this sadness that momentarily devastates monastic life, there hides a subtle and deep doubt about faith itself.

It is remarkable that the way Evagrius proposes to thwart what he presents as a dangerous temptation occupies only one brief sentence:

"One must pay no attention to them, but rather expose them with a vigilant thought when they do these things to deceive and mislead souls" $" 39$.

One must give no importance to the thoughts of sadness but simply expose or unmask them through watchful thinking. That is to say, one must be attentive in order to prevent evil thoughts or, in this case, sadness, to undermine the spiritual ramparts with which the monk protects his soul.

Finally, in the last paragraph of the chapter, he presents the opposite case: that dreams may not be induced by demons but by angels. In this case they "[...] possess a great peace of soul, an ineffable joy, suppression of impassioned thoughts by day [... $]^{\prime 40}$. Emotions and experiences in a state of vigil that follow angelic dreams are characterized by peace and joy ( $\chi \alpha \rho \dot{\alpha} \alpha \dot{\alpha} v \varepsilon \kappa \lambda \dot{\alpha} \lambda \eta \tau o \varsigma)$ that invade the monk's life.

The analysis of this chapter On Thoughts shows that for Evagrius Pontius dreams have a real influence on the dynamic of daytime life. They provoke variations in the person's emotional life and occasion the appearance of psychological phenomena such as sadness and anxiety or peace and joy, apart from any passionate disturbances they may cause.

\footnotetext{
${ }^{38}$ Ibidem.

${ }^{39}$ Ibidem.

${ }^{40}$ Ibidem.
} 
5. The Specular Function of Dreams. Evagrius points out that dreams also function as a sort of "mirror of the soul", since they reflect the person's inner state during the night. This idea, probably taken from Basil the Great, who affirms that "as our life may be, so will be our dreams"41, continues to develop deeply all through his work.

A central point in the advancement of the spiritual life is self-knowledge. People must know themselves and know the passions that affect them, and so be able to fight and eradicate them. However, this starting point hides a difficulty, since it is no easy thing to acquire this knowledge. Evagrius explains in Kephalaia Gnostica that:

"Numerous passions are hidden in the soul and since they escape us, temptations show them to us" ${ }^{\text {"42 }}$.

It would seem that the monk should have recourse to several means in order to know the weak points through which demons will try to invade his soul. In the paragraph just quoted, he explains that whatever temptations are more recurring and intense, these reveal the hidden passion or weakness. But there are other ways of knowing them. Evagrius refers in this case to thoughts that distract the monk with greater frequency during prayer and also to dreams.

When dealing with the subject in the Praktikos he says:

"When in the fantasies that occur during sleep the demons attack the concupiscible part and show us with our ready consent encounters with friends, banquets with relatives, groups of women, and other such things which offer pleasures, we become sick in this part and the passion grows in strength" ${ }^{\prime 3}$.

The key expression to interpret this paragraph is with our ready consent, since what is important in knowing the hidden passions are not the images presented during sleep but the reaction the monk has to them during the dream. In the case just quoted, the fact that the monk consents, even during sleep, to them, or accepts those fantasies related to the concupiscible appetite, indicates that the passion zone must still be healed or treated. Said in another way, dream images have no moral value and, therefore, do not indicate a determined spiritual state in an individual. What must be observed, however, are the reactions produced when faced with these images. Should they be passionate, they would possess a revealing character.

Should the case be contrary, that is to say, that the images and not the reaction reveal the state of the soul, it might be concluded that those who have reached apátheia, or gnostics, would not find themselves troubled by

\footnotetext{
${ }^{41}$ Basilius Caesariensis, Homilia in martyrem Julittam 4, PG 31, 244D, my own translation.

${ }^{42}$ Evagrius Ponticus, Kephalaia gnostica VI 52, ed. A. Guillaumont, PO 28, fasc. 1, no 134, Paris 1958, 238.

${ }^{43}$ Idem, Practicus 54, ed. A. and C. Guillaumont, SCh 171, Paris 1971, 624, transl. Sinkewicz: The Monk: A Treatise on the Practical Life, in: idem, Evagrius of Pontus, p. 107.
} 
concupiscible or irascible dreams. But this possibility is rejected by Evagrius who, in Kephlaia Gnostica, dedicated to dealing with the stage of those more advanced in the spiritual life, affirms that they may be "frightened by demons in their dreams", or rather that they are not free from troubling images ${ }^{44}$.

On the contrary, the monk's reactions to these oneiric fantasies reveal his spiritual state, concretely, if he has already reached apátheia:

"If one of the anchorites should not be troubled during sleep fantasies by terrifying or lustful visions, but rather should exercise his anger against the imaginary women who tempt him in his dreams and should strike them, and in turn, while touching women's bodies for the sake of treating them - for the demons show this as well - if he should experience no warmth but rather should counsel some of them concerning chastity, truly blessed is this man for such a degree of impassibility!" ${ }^{45}$

The level of impassibility reached by the anchorite allows him to react in a passionless way when faced by passionate dreams. To say it otherwise, dreams are a way of revealing the monk's spiritual state or the level of perfection reached by him. "We shall recognize the proofs of impassibility in the thoughts by day and in the dreams by night", he writes in the Praktikós ${ }^{46}$. Dreams are, together with thoughts, a way to recognize apátheia or impassibility.

Thus, dreams or, more concretely one's reactions when facing dream images, reveal the state of one's deepest dispositions toward virtue ${ }^{47}$. If the monk is able to dominate his passions, then that reality will necessarily manifest itself in dreams. They constitute a privileged way of knowing the depth of human soul and the weights and counter weights between vices and virtues. Evagrius does not concern himself, as occurs with number of his contemporaries, with the possibility of dreams revealing future events. For him, the revealing character of night-time fantasies stands for something far more important: the revelation of the inner self.

6. Memory and Passions in Dreams. There is another aspect of dreams that Evagrius considers and this has to do with relations established between the different faculties and potencies of the soul. The difficulty is raised because, while a person is asleep, passions cannot be excited by the senses since these are not active. Besides, demons cannot work on memory, which holds the images received through the senses during a state of vigil, since this is an intellectual faculty over which the only one who has any power is God. $\mathrm{He}$ writes about this in the Chapters on Prayer:

\footnotetext{
${ }^{44}$ Cf. idem, Kephalaia gnostica IV 60, 162, PO 28/1, 243.

${ }^{45}$ Idem, De malignis cogitationibus 29, SCh 438, 254-256, transl. Sinkewicz, p. 174.

${ }^{46}$ Cf. idem, Practicus 56, SCh 171, 630, transl. Sinkewicz, p. 107.

${ }^{47} \mathrm{Cf}$. Refoulé, Rêves et vie spirituelle d'après Évagre le Pontique, p. 497.
} 
"While the others through alteration in the body instill in the mind thoughts or mental representations or considerations, God on the other hand acts in the opposite way, visiting the mind directly and introducing within it knowledge of what He wishes, and through the mind He puts to sleep the incontinence of the body" 48 .

Evagrius then affirms that the actions of demons on a person asleep are exerted on passions and it is these that influence memory so that the fantasies proper to dreams appear. The explanation of this mechanism is detailed in his work On Thoughts:

"Therefore, it seems to me, the demons give impressions to the ruling faculty by moving the memory, for the organism is kept inactive by sleep. It is necessary to investigate in turn how they set the memory in motion. Is it perhaps through the passions? This is clearly so from the fact that those who are pure and free from passion no longer experience such a thing"49.

Evagrius asks himself in what way demons can influence the nous during sleep. Over this ruling faculty only God has direct power, and they, the demons, can only approach in an indirect way. This is the reason why it is not a valid option for demons to introduce themselves in memory while the monk sleeps in order to recover fantasies from it that can mobilize passions and, thus, push him into fault. The process is, rather, the contrary: passions are the ones moved by demons and they themselves provoke the apparition of sensitive recollections stored in the memory. He proves this statement by appealing to the case of those perfect ones who, having reached the total dominion of their passions, have no evil or impure dreams.

On this point he seems to contradict what he has written before and that we have already commented on, namely that even those who have reached apátheia continue to have troubling dreams. According to Evagrius, this is a new ruse that the demon employs to attack those more perfect and he describes it in two chapters in his treatise Chapters on Prayer. The demon, he writes, "touches a place in the brain and causes palpitations in the blood vessels" "50. The demon resorts to a direct intervention, not on the nous, but on the monk's brain - a material and organic element over which he does have power and influence - so that images charged with passion may be produced. These are the malignant spirits "who employ great cunning in altering through the brain the light associated with it and giving the mind a form, as we said previously". It is this alteration of the brain by demons that provokes a form or configuration in the mind.

${ }^{48}$ Evagrius Ponticus, De oratione 63, PG 79, 1180, transl. Sinkewicz: On Prayer, in: idem, Evagrius of Pontus, p. 199.

${ }^{49}$ Idem, De malignis cogitationibus 4, SCh 438, 164, transl. Sinkewicz, p. 155.

${ }^{50}$ Idem, De oratione 72, PG 79, 1181, transl. Sinkewicz, p. 200. 
Evagrius is then able to develop a description of the process that demons use to provoke dream images according to the spiritual state of the monk suffering them. This is a conjunction of influences between passions and memory, for one thing, and of a more direct action exerted over the brain in the case of the more perfect, for another.

The presence of passions in dreams, nevertheless, poses a quandary. As we have already seen, Evagrius analyzes numerous examples of erotic dreams that originate from one of the manifestations of epithemia, sexual appetite; however, only on one occasion and very briefly does he refer to dreams of gluttony, the other concupiscible manifestation:

"When in the fantasies that occur during sleep the demons attack the concupiscible part and show us with our ready consent encounters with friends, banquets with relatives $[\ldots]]^{\prime \prime 1}$.

And even in this case it would seem that Evagrius insists on the affectionate character of the banquet ("encounters with friends") than on the strictly passionate. It is a curious unbalance and not owed, as might be supposed, to the author bestowing little importance to gluttony. This logismos receives a careful treatment in several of his works, but it would seem that it does not intervene, like passion does, in oneiric fantasies.

Evagrius' formative tradition, the Cappadocian, is clear when affirming the dependence of dreams on physical conditions. Gregory of Nyssa dedicates a chapter in his treaty The Making of Man to dreams and there affirms that when a man sleeps both his senses and his reason are at rest, while the nutritive part continues to function:

"It seems to me, however, that when the soul is at rest so far as concerns its more excellent faculties (so far, I mean, as concerns the operations of mind and sense), the nutritive part of it alone is operative during sleep [... ${ }^{, 52}$.

Evagrius also subscribes throughout all his works to the influence of corporeal functions on dreams, leading one to think that this type of organic function produces modifications in the $\kappa \rho \hat{\alpha} \sigma ı \varsigma \varsigma$ which ends by making an impact on the production of dreams $s^{53}$.

The $\gamma \alpha \sigma \tau \rho \mu \alpha \rho \gamma^{\prime} \alpha$ or gluttony is the gastric vehemence or fasting disorder with which the monk regulates his nutritive appetite. Evagrius places it in the first place of his octave, thus assigning it the place that catalogs it as the most carnal and coarse human tendency. Nevertheless, here too there is a spiritual

\footnotetext{
${ }^{51}$ Idem, Practicus 54, SCh 171, 624, transl. Sinkewicz, p. 107.

${ }^{52}$ Gregorius Nyssenus, De opificio hominis 13, 168, SCh 6, 139, transl. H.A. Wilson: http://www. ellopos.net/elpenor/physis/nyssa-man/13.asp [17.03.2017]. On the influence of Gregory of Nyssa on Evagrius cf. I. Ramelli, Evagrius and Gregory: Nazianzen or Nyssen? Cappadocian (and Origenian) Influence on Evagrius, GRBS 53 (2013) 117-137.

${ }^{53}$ Cf. I. Hausherr, Les leçons d'un contemplatif, Paris 1960, 99-100.
} 
subtlety, for gluttony is not only a moral problem, rather it implies a return to the world of matter and objects and, therefore, a retrogression along the path of perfection. This is an inversion of the soul's tension that draws away from the heavenly and turns back to the earthly. Evagrius describes this as a desire to eat not immoderately but at moments and times that are not designated for eating, like the subtle words of demons that attempt to convince the monk to allow himself some freedoms (for example, to drink wine or eat vegetables on a feast day) that are not allowed in the style of life chosen by the anchorite:

"Against the thoughts of gluttony that compels me to eat at the ninth hour"54,

"Against the thoughts that persuade us on a feast day to show a little mercy to our body by offering it a few delicacies" $" 55$,

"Against the thoughts that on the feast day gently approach us and say to us that we might just once in a long stretch of time taste meat and wine" 56 .

This concern and vigilance over rules for nourishment, in the particular context of the solitary and monotonous life of the desert, may bring together with it an obsession with health. Eating too much or too little may put health at risk, and this worry when it is exaggerated leads to hypochondria, a behavior accompanied by fear of death or of some disease, or to the memory of other monks who have suffered or suffer painful illnesses. He writes, for example:

"Against the thought that depicts in us severe weakness from diseases that are about to arise in us from fasting and that persuades us to eat a little cooked food"s7.

Evagrian texts show that the author assigns a significant presence to gluttony and a certain virulence to the web of passions. It would not be valid to argue that the scarce or nil incidence of gluttony in dreams arises from a kind of secondary importance of the same with respect to the rest of the passions. There is no explanation sustained by theoretical motives for this situation. The motives must be looked for in Evagrius' own experience and that of the Kellia monks. The type of life they led there supposed solitude during the week with meetings with the rest of the community on Saturday evenings and Sunday mornings, occasions during which the synaxis was celebrated and also a series of lectures that allowed them not only to receive the teaching of the abbas but to express their own thoughts, concerns, difficulties and other sorrows proper to the monastic life ${ }^{58}$. These occasions were used by Evagrius as rich quarries

${ }^{54}$ Evagrius Ponticus, Antirrheticus I 7, ed. W. Frankenberg in: idem, Evagrius Ponticus, p. $475-$ 476, transl. D. Brakke in: idem, Evagrius of Pontus, p. 55.

${ }^{55}$ Ibidem I 25, ed. Frankenberg, p. 477-480, transl. Brakke, p. 58.

${ }^{56}$ Ibidem I 29, ed. Frankenberg, p. 479-480, transl. Brakke, p. 58.

${ }^{57}$ Ibidem I 59, ed. Frankenberg, p. 483-484, transl. Brakke, p. 65.

${ }^{58}$ Cf. L. Regnault, La vie quotidienne des Pères du désert en Égypte au IV siècle, Paris 1990 (chapter $\mathrm{X}$ and XIII). 
from which to extract the subtle knowledge of human psychology that characterizes his work. His personal experience, added to that of the Egyptian monks who inhabited the desert, and not only the theoretical knowledge he acquired during his formative years in Caesarea or Constantinople, are what allowed him to develop his theory about dreams.

This explains the brief appearances of gluttony in the world of Evagrian dreams against the strong presence of lust; the fact is that the experiences gathered from his own life and those of his brothers in religion indicate that dreams reproducing images related to gluttony are either scarce or non-existent. Beyond theoretical considerations that lead one to suppose that gluttony should be a similar protagonist as lust in oneiric fantasies, reality indicates to Evagrius that this is not so.

As with other authors contemporary with him, dreams possess a significant relevance in the work of Evagrius of Pontus. Nevertheless, due to the particularities of Evagrian writings, in which are exposed questions proper to theology or spirituality together with the development of psychological notions, dreams acquire an even greater importance. As a result, apart from analyzing in detail the mechanism of their formation while the monk is asleep, Evagrius bestows on dreams a wholly original function: that of revealing the state of the soul, which can be at times inaccessible for the monk in any other way. From this point of view, Evagrius is indeed a voice fifteen centuries in advance of contemporary psychology.

\section{(Summary)}

There are few late antiquity authors who pay more attention than Evagrius to dreams. For him, visions and dreams are not a way to prophesy the future or to keep in contact with the dead. They are basically a way to know oneself and the state of one's own spiritual life. After contextualizing the theories on dreams in the most significant authors of that period, I discuss the place that visions and dreams occupied in the Evagrian corpus, describing their mechanisms as a complex operation between passions, memory and the influence of demons.

\section{SNY W ŻYCIU I NAUCZANIU EWAGRIUSZA Z PONTU}

\section{(Streszczenie)}

W kwestii snów jest niewielu autorów starożytnych, którzy skupialiby na sobie większą uwagę niż Ewagriusz z Pontu. Dla niego, wizje i sny nie są narzędziem służącym do przepowiadania przyszłości lub utrzymywania kontaktu ze zmarłymi. Są one przede wszystkim środkiem umożliwiającym poznanie samego siebie i stanu swego życia duchowego. Autor artykułu, po szerszym nakreśleniu 
teorii dotyczących snów u najbardziej znaczących pisarzy tego okresu, omawia te wypowiedzi z korpusu dzieł Ewagriusza, które dotyczą wizji i snów, opisując ich mechanizmy jako złożony proces między namiętnościami, pamięcią i oddziaływaniem demonów.

Key words: Evagrius of Pontus, Dreams, Psychology.

Słowa kluczowe: Ewagriusz z Pontu, sny, psychologia.

\section{BIBLIOGRAPHY}

\section{Sources}

Ambrosius Mediolanensis, De excessu fratris Satyri, PL 16, 1345-1414.

Ambrosius Mediolanensis, De Spiritu Sancto, PL 16, 731-826.

Ambrosius Mediolanensis, Epistulae, PL 16, 913-1342.

Aristoteles, De divinatione per somnum, ed. W.D. Ross, in: Aristoteles, Parva Naturalia (with extensive commentary in English), Oxford, 1955, transl. J.I. Beare: On Prophesying by Dreams, New York 1966.

Athanasius Alexandrinus, Epistulae festales, PG 26, 1360-1444.

Augustinus Hipponensis, De genesi ad litteram, ed. J. Zycha. CSEL 28/1, Vindobonae $1894,1-435$.

BASILIUS CAESARIENSIs, Enarratio in Isaiam prophetam, PG 30, 117-6689, transl. N.A. Lipatov: St. Basil the Great, Commentary on the Prophet Isaiah, Cambridge 2001.

Basilius CAesariensis, Homilia in martyrem Julittam, PG 31, 237-261.

Basilius Caesariensis, Epistulae, PG 32, 220-1112, transl. R. Deferrari, vol. 1: Letters 1-58, Cambridge MA 1926, 24-25.

Evagrius Ponticus, Antirrheticus, ed. W. Frankenberg in: idem, Euagrius Ponticus, Abhandlungen der königlichen Gesellschaft der Wissenschaften zu Göttingen, Philologisch-historische Klasse, Neue Folge 13/2, Berlin 1912, 472-544, transl. D. Brakke: Evagrius of Pontus. Talking Back. A Monastic Handbook for Combating Demons, Collegeville Minn. 1989.

Evagrius Ponticus, De malignis cogitationibus, ed. A.C. Guillaumont - P. Géhin, SCh 438, Paris 1998, transl. R.E. Sinkewicz: On Thoughts, in: idem, Evagrius of Pontus. The Greek Ascetic Corpus, Oxford Early Christian Studies, Oxford 2003, 136-182.

Evagrius Ponticus, De oratione, PG 79, 1165A - 1200C, transl. R.E. Sinkewicz: On Prayer, in: idem, Evagrius of Pontus. The Greek Ascetic Corpus, Oxford Early Christian Studies, Oxford 2003, 183-209.

Evagrius Ponticus, Kephalaia gnostica, ed. A. Guillaumont, PO 28, fasc. 1, no 134, Paris 1958.

Evagrius Ponticus, Practicus, ed. A. and C. Guillaumont, SCh 171, Paris 1971, transl. R.E. Sinkewicz: The Monk: A Treatise on the Practical Life, in: idem, Evagrius of Pontus. The Greek Ascetic Corpus, Oxford Early Christian Studies, Oxford 2003, 91-114.

Gregorius Magnus, Dialogi, ed. A. de Vogüé - P. Antin, SCh 265, Paris 1980.

Gregorius Magnus, Moralia in Iob, ed. R. Guillet - A. de Gaudemaris, SCh 32bis, Paris 1975.

Gregorius Nazianzenus, Carmina, PG 37, 969-1600.

Gregorius Nyssenus, De opificio hominis, ed. J. Laplace, SCh 6, Paris 1944, transl. H.A. Wilson: http://www.ellopos.net/elpenor/physis/nyssa-man/13.asp [16.03.2017]. 
Hieronymus, Commentaria in Ieremiam, PL 24, 705-936.

Hieronymus, De virginitate beatae Mariae, PL 23, 193-216.

Hieronymus, Epistula 22 [ad Eustochium], PL 22, 394-425.

JoAnnes Chrysostomus, In Acta Apostolorum homiliae, PG 60, 13-584, transl. M. Merino Rodríguez: Juan Crisóstomo, Homilías a los Hechos de los Apóstoles, Biblioteca de Patrística 80-81, Madrid 2010.

Joannes Chrysostomus, In epistulam ad Romanos homiliae, PG 60, 391-682, transl. B. Bejarano: San Juan Crisóstomo, Homilías sobre la Carta a los Romanos, t. 1-2, Apostolado Mariano, Los Santos Padres 21-22, Seville 1990.

Johnnes Chrysostomus, In Matthaeum homiliae, PG 57, 13 - 58, 794, ed. and transl. D. Ruíz Bueno: Obras de San Juan Crisostomo, I-II: Homilias sobre el Evangelio de San Mateo, Biblioteca de Autores Cristianos, ed. bilingüe griego/español, Madrid 2007.

Macrobius, Commentarii in Somnium Scipionis, ed. J.A. Willis, vol. 2, Bibliotheca Scriptorum Graecorum et Romanorum Teubneriana, Leipzig 1970², transl. W.H. Stahl: Commentary on the Dream of Scipio by Macrobius, New York 1990.

Palladius, Historia Lausiaca, ed. C. Butler: The Lausiac History of Palladius, vol. 1-2: The Greek Text edited with introduction and notes, Texts and Studies VI/1-2, Cambridge 1904, transl. R.T. Meyer: Palladius, The Lausiac History, Ancient Christian Writers 34, London 1965.

Synesius Cyrenensis, De insomniis, PG 66, 1282-1320.

\section{Literature}

Amat J., Songes et visions. L'au-delà dans la littérature latine tardive, Paris 1985.

BARr J.G., Willing to Know God: Dreamers and Visionaries in Later Middle Ages, Columbus 2010.

Bilbija J., The Dream in Antiquity: Aspects and Analyses, Amsterdam 2012.

Casiday A., Evagrius Ponticus, London 2006.

Dulaey M., Le rêves dans la vie et la penseé de saint Augustin, Paris 1973.

Flannery-Dailey F., Dreamers, Scribes and Priests. Jewish Dreams in the Hellenistic and Roman Eras, Leiden 2004.

Frankenberg W., Euagrius Ponticus, Abhandlungen der königlichen Gesellschaft der Wissenschaften zu Göttingen, Philologisch-historische Klasse, Neue Folge 13/2, Berlin 1912, 472-544, English translation - D. Brakke: Evagrius of Pontus. Talking Back. Antirrhêtikos. A Monastic Handbook for Combating Demons, Collegeville Minn. 1989.

GNuse R., Dream and Dream Reports in the Writings of Josephus, Leiden 1997.

Gollnick J., The Religious Dreamworld of Apuleius' "Metamorphoses". Recovering a Forgotten Hermeneutic, Ontario 1999.

Gray R., Prophetic Figures in Late Second Temple Jewish Palestine: The Evidence from Josephus, Oxford 1993.

Hausherr I., Les leçons d'un contemplatif, Paris 1960.

Husser J., Dreams and Dream Narratives in the Biblical World, Sheffield 1999.

Koet B., Introducing Dreaming from Hermas to Aquinas, in: Dreams as Divine Communication in Christianity: From Hermas to Aquinas, ed. idem, Leuven 2012, 1-21.

Konstantinovsky J., Evagrius of Pontus: The Making of a Gnostic, Farnham 2013.

Kruger S., Dreaming in the Middle Ages, Cambridge 1996.

Rameldi I., Evagrius and Gregory: Nazianzen or Nyssen? Cappadocian (and Origenian) Influence on Evagrius, GRBS 53 (2013) 117-137. 
REFoulÉ F., Rêves et vie spirituelle d'après Évagre le Pontique, VS Supplément 56 (1961) 470-516.

Regnault L., La vie quotidienne des Pères du désert en Égypte au IVe siècle, Paris 1990.

Sinkewicz R.E., Evagrius of Pontus. The Greek Ascetic Corpus, Oxford Early Christian Studies, Oxford 2003. 